\title{
A stable Cenozoic geologic time scale is indispensable
}

Department of Geological Sciences, University of Texas at Austin, Austin, Texas 78712,USA. Email: amos.salvador@mail.utexas.edu

A stable, standard geologic time scale is indispensable for the clear and precise communication among geologists; it is a basic tool of geologic work. Considerable progress has been made to achieve such a stable time scale. However, during the last few years several proposals have been made to modify the Cenozoic section of the geologic time scale that threaten to destabilize it. Seven articles published in Episodes since 2000 that could contribute to this destabilization are discussed. They provide excellent examples of the profusion of different terminologies, hierarchies, and stratigraphic relationships that have been proposed: to eliminate the Tertiary and the Quaternary or to raise their rank to suberathems; to extend the Neogene to the present; to make the Quaternary a formal subsystem of the Neogene, or consider it an informal stratigraphic unit; to eliminate the Holocene, and to decouple the base of the Pleistocene from the base of the Quaternary. If adopted, these proposals would cause nothing but great confusion and controversy. They disregard the clear preferences of geologists the world over as reflected by the terminology they have been using for many decades. Common sense would dictate the continued use of this terminology in its current, widely accepted form.

\section{Introduction}

There is no doubt that a stable standard geologic time scale - an international Standard Global Chronostratigraphic (Geochronologic) Scale - with precise numerical dates for its units and their boundaries, to which every geologist in the world can refer, is a basic tool of geology, and indispensable for the advancement of geologic studies. Such a scale makes it possible for all geologists to communicate clearly and precisely among themselves and, as a result, to cooperate effectively in working to decipher the geologic history of the Earth.

Notable progress has been made during the last 50 years in reaching such a stable standard geologic time scale thanks to the work of the International Commission on Stratigraphy (ICS) of the IUGS.

Regarding the Cenozoic time scale, the current preference of the vast majority of geologists has been documented by an extensive review of the geologic literature published since 1980 (Salvador, 2006). This review covers 19 journals of extensive distribution, plus a considerable number of geologic maps, time scales, geology textbooks and the GeoRef. Together with an additional investigation of the mid-20th century geologic literature, it clearly reveals that the geologic time scale most widely accepted and used has the Cenozoic Erathem/Era comprising the Tertiary and the Quaternary systems/periods, with the Tertiary comprising the Paleogene and Neogene subsystems/subperiods. The Paleogene includes the Paleocene, Eocene, and Oligocene series/epochs, the Neogene comprises the Miocene and Pliocene series/epochs, and the Quaternary includes the Pleistocene and Holocene series/epochs (Figure 1).

\begin{tabular}{c|c|l|l}
\hline \multirow{2}{*}{$\begin{array}{c}\text { Erathem } \\
\text { (Era) }\end{array}$} & \multicolumn{2}{|c|}{$\begin{array}{l}\text { System and Subsystem } \\
\text { (Period and Subperiod) }\end{array}$} & $\begin{array}{l}\text { Series } \\
\text { (Epoch) }\end{array}$ \\
\hline \multirow{3}{*}{ Cenozoic } & \multicolumn{2}{|c|}{ Quaternary } & $\begin{array}{l}\text { Holocene } \\
\text { Pleistocene }\end{array}$ \\
\cline { 2 - 4 } & Tertiary & Neogene & $\begin{array}{l}\text { Pliocene } \\
\text { Miocene }\end{array}$ \\
\cline { 2 - 3 } & & Paleogene & $\begin{array}{l}\text { Oligocene } \\
\text { Eocene } \\
\text { Paleocene }\end{array}$ \\
\hline
\end{tabular}

Figure 1 The most widely accepted Cenozoic time scale in current use.

However, during the last few years several proposals have been made to modify this widely accepted Cenozoic time scale, each contributing in different ways to destabilize it. Only those proposals published in Episodes during the last 6 years will be discussed in this note. They provide an excellent example of the profusion of different terminologies, hierarchies and stratigraphic relationships proposed to modify the Cenozoic time scale.

\section{Proposed modifications to the Cenozoic time scale}

Gradstein (2000) presented a Cenozoic time scale in which the Tertiary was eliminated and the Cenozoic is shown as composed of the Paleogene, Neogene and Quaternary systems/periods.

Gradstein and Ogg (2002) and Gradstein et al. (2004) offered Cenozoic time scales in which both the Tertiary and the Quaternary were left out, the Cenozoic including the Paleogene and Neogene systems/periods, and the Neogene extending to the present. Ogg (2004) also extended the Neogene to the present but stated (p. 126) that the Quaternary "remains a very useful climate-based chronostratigraphic term" that would be defined "as a 'composite epoch' (equal to the Holocene and Pleistocene epochs plus the Gelasian stage of the Pliocene; or simply the geologic time interval 'younger than 2.6 Ma')". He added (p. 126): "This 'composite epoch' would have no formal placement in the hierarchy of chronostratigraphic units".

Pillans (2004) also proposed to eliminate the Tertiary, and to extend the Neogene System to the present. He retained the Quaternary as a formal subsystem of the Neogene and included in it the 


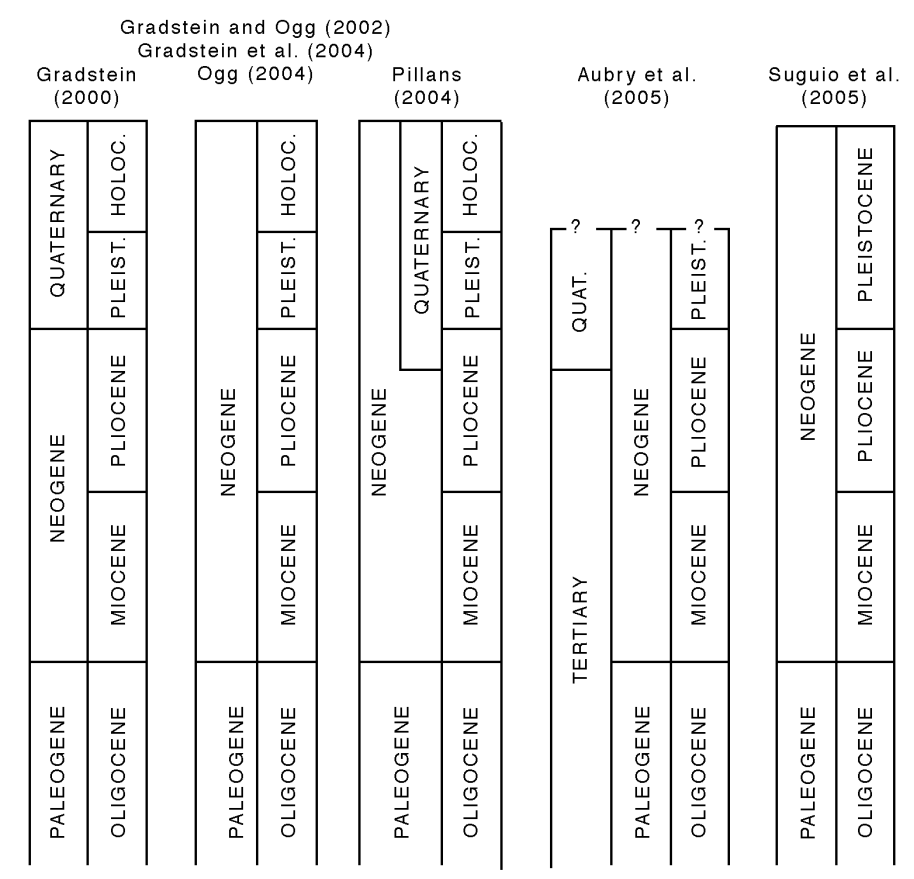

Figure 2 The subdivision of Cenozoic time scale by different authors.

Gelasian Stage of the Pliocene and the Pleistocene and Holocene series.

Aubry et al. (2005) presented a Cenozoic time scale that includes the Tertiary and the Quaternary as sub-erathems/sub-eras of the Cenozoic Erathem/Era - thus acknowledging the universal acceptance and use of the Tertiary and the Quaternary by geologists from around the world. The Paleogene and the Neogene were shown as systems/periods, with the Neogene extending to the present. The Holocene was apparently eliminated as the upper series of the Quaternary/Neogene. The base of the Quaternary was decoupled from the base of the Pleistocene, and the Quaternary, a unit of superior rank was shown as contained entirely within the Neogene, a unit of inferior rank.

Finally, Suguio et al. (2005), proposed to eliminate the Tertiary and the Quaternary, to extend the Neogene to the present including the Miocene, Pliocene, and Pleistocene but also omitting the Holocene and extending the Pleistocene to the present. They added (p. 199) that it may be possible "to consider the Quaternary as an informal chronostratigraphic unit, whose beginning could be located at the base of the Gelasian Stage, coincident with the commencement of the Pleistocene Epoch at about 2.6 My".

Figure 2 shows the subdivisions by different authors memtioned above.

\section{Are these proposed modifications sensible and necessary?}

This profusion of proposals for different terminologies, hierarchies, and stratigraphic relationships does not help to achieve a stable, standard geologic time scale for the Cenozoic, particularly because most of the proposals ignore the terminology, hierarchies, and stratigraphic relationships that geologists worldwide have accepted and used for many decades, and continue to use today.

To eliminate the Tertiary and the Quaternary from the Cenozoic time scale clearly ignores reality. As systems of the Cenozoic Erathem, they are too deeply rooted in the geologic literature to be willfully eradicated.
As I recently documented (Salvador, 2006), Tertiary is a stratigraphic term that has been used, and continues to be extensively used, with the same meaning in all countries and regions of the world from which I obtained information. Since 1980, Tertiary was used in the title, time scales, or in the legends of maps and cross sections of 3037 articles in the 19 geologic journals reviewed. In the last 10 years, 1257 articles used Tertiary (Salvador, 2006, p. 25). Tertiary was used in all geologic maps I reviewed, and in the vast majority of time scales. In all cases, Tertiary was used as the lower system/period of the Cenozoic Erathem/Era.

Past attempts to abandon the Tertiary have been ignored. Recent attempts will also be ignored. The Tertiary has been, and continues to be, an extremely useful stratigraphic unit for discussing and mapping stratigraphy at a local or regional scale, in surface or subsurface studies, in biostratigraphy, magnetostratigraphy, sequence stratigraphy and many other fields of stratigraphic investigation. The use of Tertiary by geologists from all over the world has not declined in the last 25 years and does not look like it is going to anytime soon. The Tertiary has passed with high marks the test of use over time. This is the reality of the status of the Tertiary in stratigraphic terminology.

In the review of the geological literature mentioned above, I also found that Paleogene and Neogene have seen increasing use during the last 25 years, mostly as sub-systems/sub-periods of the Tertiary System/Period, but also as systems of the Cenozoic when Tertiary has not been used. This increasing acceptance and use of Paleogene and Neogene does not mean that the Tertiary should be eliminated from the geologic time scale. It should not be a question of either Tertiary or Paleogene and Neogene; we need all three of them, as we need Cenozoic, Paleocene, Eocene, Oligocene, Miocene, and Pliocene - and the stages of these series/epochs - to express various degrees of precision in stratigraphic assignation and dating. There should be room for a flexible terminology. Geologists and geological organizations should be given a choice of which terms better fit their needs.

To eliminate the Quaternary from the geologic time scale is also unrealistic. The Quaternary is undoubtedly the chronostratigraphic unit most frequently, consistently, and uniformly used by geologists from around the world in journal articles, geologic maps, time scales and other geologic publications. A search of GeoRef indicated that just since 1980, Quaternary had appeared in the title of geologic publications 25,385 times, and 156,567 times other than in the title.

There is at present debate concerning the desirability of lowering the base of the Quaternary to correspond with the base of the Gelasian Stage, currently the uppermost stage of the Pliocene, and of decoupling the base of the Quaternary from the base of the Pleistocene. This controversy can be best resolved by an international group of experts on this subject that would examine and discuss the facts, following the procedures established in the ICS Guidelines for such cases. Regardless, the Quaternary should remain the upper system of the Cenozoic and the base of the Pleistocene should not be decoupled from the base of the Quaternary.

To extend the Neogene to the present is also inadvisable. As defined by Hörnes in the Vienna basin, the Neogene includes only the Miocene and Pliocene (Hörnes, 1851, 1853). But even if Hörnes' original definition is interpreted as indicating that his Neogene extended into the Pleistocene, further use of the term during the remaining years of the 19th century and during the 20th century first in central Europe, eventually in the rest of the world - leave no doubt that the vast majority of geologists employ the Neogene as the upper subsystem/subperiod of the Tertiary, including only the Miocene and Pliocene series/epochs. In the extensive review of the geologic literature (Salvador 2006), none of the publications extended the Neogene to the present. 


\section{So what would be preferable?}

To eliminate the Tertiary and the Quaternary from the standard geologic time scale, or to raise their rank to sub-erathems/sub-eras; to extend the Neogene to the present; to make the Quaternary a formal subsystem of the Neogene, or to consider it an informal stratigraphic unit, to eliminate the Holocene; and to decouple the base of the Pleistocene from the base of the Quaternary would cause great confusion and controversy. These changes disregard the preference of geologists from around the world and ignore the terminology in common use today. Why not continue using the terminology, hierarchies, and stratigraphic relationships that geologists have been using for many decades and continue to use today? This is what common sense dictates.

\section{References}

Aubry, M. P., Berggren, W. A., van Couvering, J., McGowran, B., Pillans, B., and Hilgen, F., 2005, Quaternary: status, rank, definition, survival: Episodes, v. 28, no. 2, p. 118-120.
Gradstein, F. M., 2000, Future directions within the International Commission on Stratigraphy (ICS): Episodes, v. 23, no. 4, p. 283-284.

Gradstain, F. M., and J. G. Ogg, 2002, Future directions in stratigraphy: Episodes, v. 25, no. 3, p. 203-208.

Gradstein, F. M., Ogg, J. G., Smith, A. G., Bleker, W., and Lourens, L. V., 2004, A new geologic time scale, with special reference to Precambrian and Neogene: Episodes, v. 27, no. 2, p. 83-100.

Hörnes, M., 1851, Die fossilen Mollusken des Tertiär-Beckens von Wien. Nr. I. Conus. Jahrbuch der Kaiserlich-Koniglichen Geologischen Reichsanstalt, 2:93-134.

Hörnes, M., 1853, Mittheilungen an Professor BRONN gerichtet: Neues Jahrbuch für Mineralogie, Geologie, Geognosie und Petrefakten-Kunde, p. 806-810.

Ogg, J., 2004, Introduction to concepts and proposed standardization of the term "Quaternary": Episodes, v. 27, no. 2, p. 125-126.

Pillans, B., 2004, Proposal to redefine the Quaternary: Episodes, v. 27, no. 2, p. 127.

Salvador, A., 2006, The Tertiary and the Quaternary are here to stay: AAPG Bulletin, v. 90, no. 1, p. 21-30.

Suguio, K., Ernandes Martins Sallun, A., and Soares, E. A. A., 2005, Quaternary: "Quo Vadis"?: Episodes, v. 28, no. 3, p. 197-200.

\section{List of CGMW Maps Available}

\section{Geological Maps}

- Geological Atlas of the World 1:10 M scale, 22 sheets (completed in 1984)

- International Geological Map of Africa (3rd edition) 1:5 M scale, 6 sheets (completed in 1990)

- Geological Map of the Middle East 1:5 M scale, 1 sheet (1993)

- Geological Map of South and East Asia 1:5 M scale, 4 sheets (+ 2 legend sheets) (1990)

- International Geological Map of Europe and the Mediterranean Regions

1:1.5 M scale, 44 sheets (1964-2000)

- International Geological Map of Europe and the Mediterranean Regions

1:1.5 M scale, 2 sheets (East and West)

\section{Tectonic Maps}

- Seismotectonic Map of the Middle East 1.5 M scale, 1 sheet (1992)

- International Tectonic Map of Europe 1.5 M scale, 5 sheets $(1996 / 1998)$

\section{Metallogenic Maps}

- Metallogenic Map of South America 1:5 M scale, 2 sheets (1983)

- Metallogenic Map of South and East Asia 1:5 M scale, 4 sheets (+1 legend sheet) (1985)

- International Mineral Deposits (Metallogenic) Map of Africa

1:5 M scale. Sheet No.1 (NW Africa) (1991)

Sheets 5 \& 6 (south of equator) (1999)

- Metallogenic Map of Europe 1:2.5 M scale, 9 sheets (completed in 1983)

- Mineral Atlas of the World

1:10 M scale, only published: Sheet No.9 (Europe and neighboring countries) (1998)

\section{Quaternary Maps}

- The Sahara in the Holocene 1:5 M scale, 1 sheet (1993)

- Maps of the World Environments during the Last Two Climatic Extremes

1:25 M scale, 2 maps in 4 sheets (1999)

\section{Metamorphic Map}

- Metamorphic Map of South and East Asia 1:10 M scale, 1 sheet (1984).

\section{Hydrogeological Maps}

- Hydrogeological Map of Europe 1:1.5 M scale, 21 sheets.

- Mapa Hidrogeologico de America del Sur 1:5 M scale, 2 sheets (1996)

\section{Digital Maps}

- Geological Map of South and East Asia 1:5 M scale (1990) in Arclnfo format

- Sheets 5 and 6 of the International Metallogenic Map of Africa

1:5 M scale in Arclnfo $®$, ArcView $®$ and Arc Explorer $\AA$ formats

- Maps of the World Environments during the Last Two Climatic Extremes

1:25 M scale in Arclnfo format

For details, please visit the CGMW website: http://ccgm.club.fr/page4.html Commission for the Geological Map of the World 